\title{
THE POSSIBLY HYPOGENE KARSTIC IRON ORE DEPOSIT OF WARDA NEAR AJLOUN (NORTHERN JORDAN), ITS MINERALOGY, GEOCHEMISTRY AND HISTORIC MINE
}

\author{
HIPOGENI KRAŠKI IZVOR ŽELEZOVIH SEDIMENTOV V \\ WARDI PRI AJLOUNU (SEVERNA JORDANIJA): MINERALOGIJA, \\ GEOKEMIJA IN ZGODOVINSKI RUDNIK
}

\author{
Ahmad AL-MALABEH ${ }^{1}$, Stephan KEMPE ${ }^{2}$, Horst-Volker HENSCHEL ${ }^{3}$ \\ Heiko HOFMANN ${ }^{4} \&$ Heinz Jürgen TOBSCHALL ${ }^{5}$
}

\begin{abstract}
UDC 553.3(569.5)

Ahmad Al-Malabeh, Stephan Kempe, Horst-Volker Henschel, Heiko Hofmann \& Heinz Jürgen Tobschall: The possibly hypogene karstic iron ore deposit of Warda near Ajloun (Northern Jordan), its mineralogy, geochemistry and historic mine

In this study the iron ore deposit of the historic Warda mine (District of Ajloun, Northern Jordan) and its speleological importance is discussed. The number of known dissolutional caves in Jordan is very low, in spite of the fact, that large sections of the country are underlain by Cretaceous limestone. The only large cave yet discovered is Al-Daher Cave, a hypogene maze cave (Kempe et al. 2006). The Warda Iron Deposit was mined during the time of the crusades by one of Saladin's officers to build and stock the castle of Ajloun. The survey shows that the mine consists of two larger rooms, together about $1000 \mathrm{~m}^{2}$ in area. Much of the mine's floor is now covered with recent flood sediments $\left(680 \mathrm{~m}^{2}\right)$, up to over $2 \mathrm{~m}$ deep. The mine cuts natural cavities, fissures with speleothems and a collapse hall in limestone, that may or may not have been created by a collapsed mine ceiling. Calculating the mine volume conservatively, a total of about $1100 \mathrm{t}$ of elemental iron may have been extracted. Mineralogical investigation (XRD) shows, that the iron ore is goethitic/limonitic with noticeable hematite contents. Geochemical (XRF) analysis shows that the goethite is very pure; impurities of main elements sum up to $1 \%$ only. Among the trace-elements W (248 ppm), As (168 ppm) and Co (124 ppm)
\end{abstract}

\begin{abstract}
Izvleček UDK 553.3(569.5)
Ahmad Al-Malabeh, Stephan Kempe, Horst-Volker Henschel, Heiko Hofmann \& Heinz Jürgen Tobschall: Hipogeni kraški izvor železovih sedimentov $v$ Wardi pri Ajlounu (Severna Jordanija): mineralogija, geokemija in zgodovinski rudnik

$\mathrm{V}$ študiji obravnavamo železovo rudišče Warda (okrožje Ajloun v Severni Jordaniji) in njegov speleološki pomen. Število kraških jam v Jordaniji je majhno, kljub dejstvu, da je kamninska podlaga velikega dela dežele kredni apnenec. Edina znana velika jama je hipogeni blodnjak (maze cave) Al-Daher, (Kempe et al. 2006). Rudo v Wardi je v času križarskih vojn kopal eden od Saladinovih častnikov. Železo iz rudnika so uporabili pri gradnji Ajlounskega gradu. Rudnik sestavljata dve večji dvorani s skupno površino $1000 \mathrm{~m}^{2}$. Tla $\mathrm{v}$ rudišču so danes pokrita $\mathrm{z}$ do dva metra debelo plastjo poplavnih sedimentov (volumen $680 \mathrm{~m}^{3}$ ). Rudišče seka več naravnih votlin in s sigo zapolnjenih razpok, kakor tudi podorno dvorano $\mathrm{v}$ apnencu, katere izvor ni jasen. Iz ocene prostornine izkopa smo določili, da so v rudniku nakopali približno 1100 ton čistega železa. Mineraloške (rentgenska difrakcija) raziskave so pokazale, da je ruda pretežno goethitno-limonitna $\mathrm{z}$ opazno vsebnostjo hematita. Geokemične (rentgenska fluorescenca) analize pa kažejo na zelo čist goethite, $\mathrm{z}$ vsega enim odstotkom nečistoč. Med elementi v sledovih so najbolj pogosti W (248 ppm), As (168 ppm) in Co (124 ppm) vseh ostalih pa je manj kot 37 ppm. Prejšnje raziskave so pokazale da se ruda razteza na površini
\end{abstract}

${ }^{1}$ Prof. Dr. Ahmad Al-Malabeh, Hashemite University, Department of Earth and Environmental Sciences, P.O. Box 150459, Zarka 13115, Jordan, email: Am@hu.edu.jo;

2 Prof. Dr. Stephan Kempe, Inst. für Angewandte Geowissenschaften, Technische Universität Darmstadt, Schnittspahnstr. 9, D-64287 Darmstadt, Germany, email: kempe@geo.tu-darmstadt.de;

${ }^{3}$ Dr. Horst-Volker Henschel, Henschel \& Ropertz, Am Markt 2, D-64287 Darmstadt, Germany, email: h-v.henschel@henschelropertz.de;

${ }^{4}$ Dr. Heiko Hofmann, Inst. für Angewandte Geowissenschaften, Technische Universität Darmstadt; Schnittspahnstr. 9, D-64287 Darmstadt, Germany, email: heiko@geo.tu-darmstadt.de;

${ }^{5}$ Prof. Dr. Heinz Jürgen Tobschall, Lehrstuhl für Angewandte Geologie der FAU Erlangen-Nürnberg, Schloßgarten 5, 91054 Erlangen, email: htobscha@geol.uni-erlangen.de.

Received/Prejeto: 15.11.2007 
show the highest concentrations, with all others $<37(\mathrm{Ba}) \mathrm{ppm}$. Former prospecting results show that the deposit has a spatial extent of $300 \times 200 \mathrm{~m}$ with a maximal thickness of about $10 \mathrm{~m}$. Textural, mineralogical and geochemical criteria suggest that the ore body could be of speleogene origin, i.e. deposited in a hypogene, deep phreathic setting, possibly before regional uplift or even prior to the maximal burial depth. A possibly similar ore-body is for example described from the gigantic Lower Cretaceous and sand-filled cave of Wülfrath (North RhineWestphalia, Germany) (Drozdzewski et al. 1998).

Key words: Hypogene karst, iron ore deposition, lagerstaetten genesis, geochemistry, mineralogy, historic mining, Warda, Ajloun, Jordan.
300 x $200 \mathrm{~m}$ v debelini do $10 \mathrm{~m}$. Teksturni, mineraloški in geokemični kriteriji govorijo, da je rudno telo verjetno speleogeno, odloženo $\mathrm{v}$ hipogenem, globoko freatičnem okolju, verjetno še pred regionalnem dvigom, mogoče še pred maksimalno globino pokopa. Podobno rudno telo je opisano v gigantski spodnjekredni jami napolnjeni s peščenimi sedimenti v Wülfarthu (Severni Ren -Westfalija, ZR Nemčija) (Drozdzewski et al. 1998).

Ključne besede: Hipogeni kras, sedimenti železove rude, geneza lagerstaeten, geokemija, mineralogija, zgodovinsko rudišče, Warda, Ajloun, Jordanija.

\section{INTRODUCTION}

Since 2003 the first three authors are systematically exploring caves and karst and their genesis in Jordan. While the eastern part of Jordan is composed of a lava plateau where lava caves occur (Kempe et al. 2008), much of the eastern part of Jordan is formed by Upper Cretaceous limestone. Nevertheless only a few dissolutional caves are known in the country up today. The largest one is $\mathrm{Al}$ Daher Cave discovered in 1995 (Kempe et al. 2006). It is a maze cave of intersecting halls and passages developed along NE-SW and SE-NW striking joints and limited to an area of $70 \times 70 \mathrm{~m}$. It is lacking any morphological or sedimentological signs of an epigene cave development caused by turbulently flowing ground water or sinking surface streams such as anastomoses, scalloped walls, canyons, or water-transported gravels or sand. Instead, the morphology is that of a typical hypogene cave (i.e., Klimchouk 2007) with irregular halls connected by small passages developed along a limited set of limestone beds. The cave contains only residual sediments, i.e. chert nodules and fine-grained silts. Most probably it was formed by ascending anaerobic $\mathrm{H}_{2} \mathrm{~S}$ or $\mathrm{CH}_{4}$ containing water that mixed with oxygenated water, thereby creating dissolutional capacity by bacterially mediated oxidation of these gases (Kempe et al. 2006). The only other larger caves in limestone are: the $140 \mathrm{~m}$ long Kufranja Cave near Ajloun Castle (Al-Malabeh et al. 2007), an essentially tectonic cave and the $114 \mathrm{~m}$ long Abu-Dhahi Cave near Khreisan Village/Al-Mafraq, a small phreatic cave probably developed in groundwater bypassing a former valley fill.

Here we report about a cavity mostly created by historic mining that extracted oxidic iron ores. Iron was an important commodity to ancient Near East cultures since the beginning of the Iron Age at 1200 BC. Since Jordan is lacking large-scale iron ore deposits (e.g., Bender 1974), small ore occurrences were mined locally and extracted at the surface in open pits or underground in short tunnels. Where there were natural cavities, these provided for a much easier extraction. One of these areas is found near Ajloun (Fig. 1, 2), where a mine is still accessible and several entrances are noticed (Fig. 3, 5). This mine is however threatened by a nearby quarry or road development.

\section{GEOLOGIC SETTING OF JORDAN AND THE RESEARCH AREA}

Many prominent structural features are present in Jordan. They are closely related to the regional geology and tectonics of the Eastern Mediterranean area. Several intraplate deformation phases affected the northern Arabian Plate between the Late Paleozoic and the Cenozoic. Major rifting episodes occurred in the Late Carboniferous to Permian, Middle to Late Triassic, and at the end of the Early Cretaceous. Three major deformational structures characterize the region (e.g., Quennell 1958,
Garfunkel et al. 1981, Freund et al. 1970, Barazangi 1983, Al-Malabeh 1994).

Field investigations, aerial photographs, Google Earth pictures and satellite images indicate that three principal fault systems exist in the area of the Warda Iron Deposit (WID), these are:

1. The Syrian Arc: It is composed of a series of anticlines and synclines in Central Syria (the Palmyra fold belt), Jordan and Sinai (Levantine fold belt) forming an 


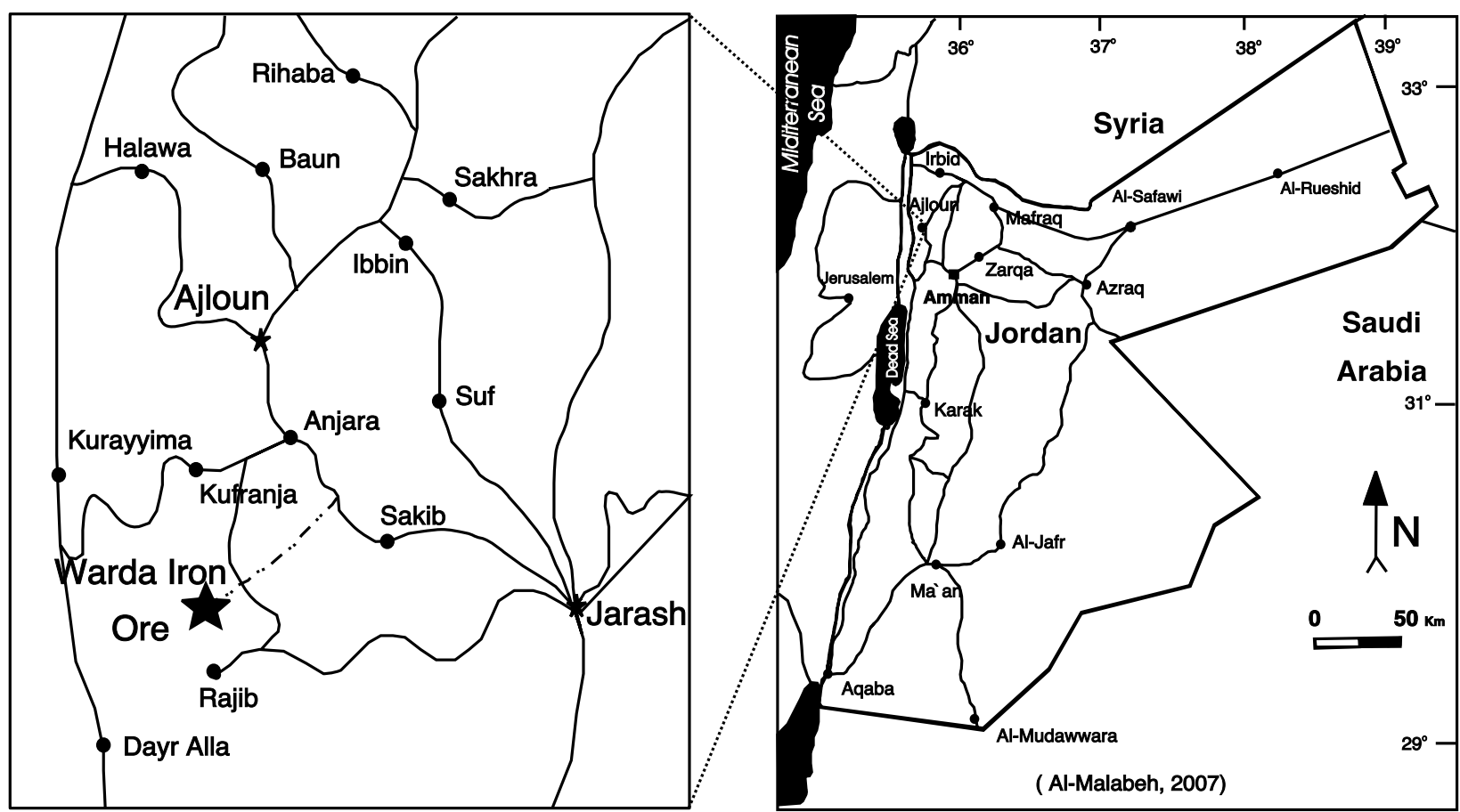

Fig 1: Location map of Warda Iron Deposit in the northern part of Jordan.
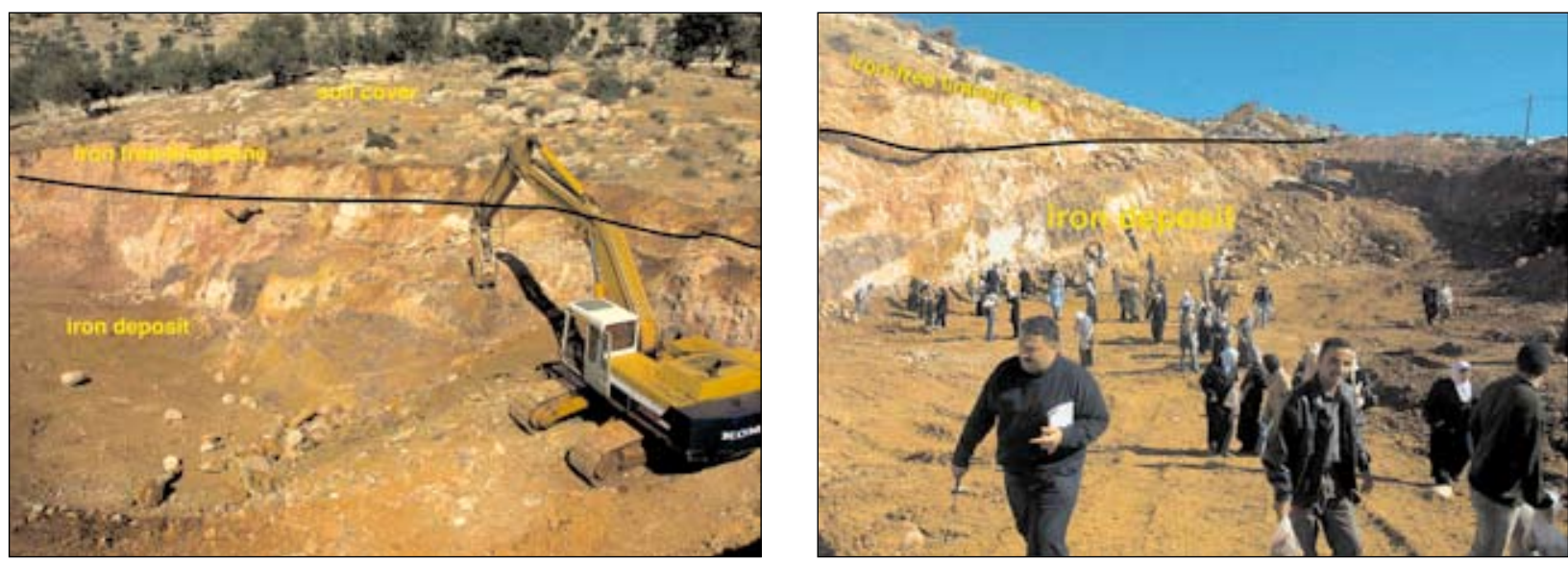

Fig. $2 a, b$ : Views of the current pit mine that exposes the iron ore body underneath a fragmented limestone layer. The pictures were taken in November 2005.

S-shaped fold belt that crosses the Dead Sea Transform Fault. In Jordan examples of these folds are the Amman, Hallabat and Wadi Shu'eib Structures. Most of the folds are asymmetrical and locally faulted by normal and strike-slip faults. Three stages of folding occurred, i.e. before the Jurassic, in the Late Mesozoic-Early Cenozoic, and in the Late Eocene-Oligocene.

2. The Erythrean Fault System: This structure consists of NW-SE and E-W oriented normal and strike-slip faults from the Late Miocene to Early Pliocene (Kazmin 2002). During the Erythrean phases many of the faults and rifts in Jordan were formed such as the Wadi Sirhan graben and the Karak-Fayha fault.
3. The Dead Sea Transform Fault: It formed in the Cenozoic as a result of the breaking off of the Arabian plate from the African plate. The total left-lateral slip along the fault amounted of $107 \mathrm{~km}$ since the Cretaceous (e.g., Quennell 1958, Freund et al. 1970, Garfunkel 1981, Girdler 1990, Al-Malabeh et al. 2003).

Major trends are N-S, E-W and NNE-SSW. Along these directions, the rocks have been jointed and fractured substantially. Field investigation shows that the WID occurs as a belt extending in a NNE-SSW direction. Along this direction a fault with fault breccia is recorded. The ore occurs in Upper Cretaceous limestone of Cenomanian-Touranian age in what locally known as the Wadi Al-Sir Formation. 


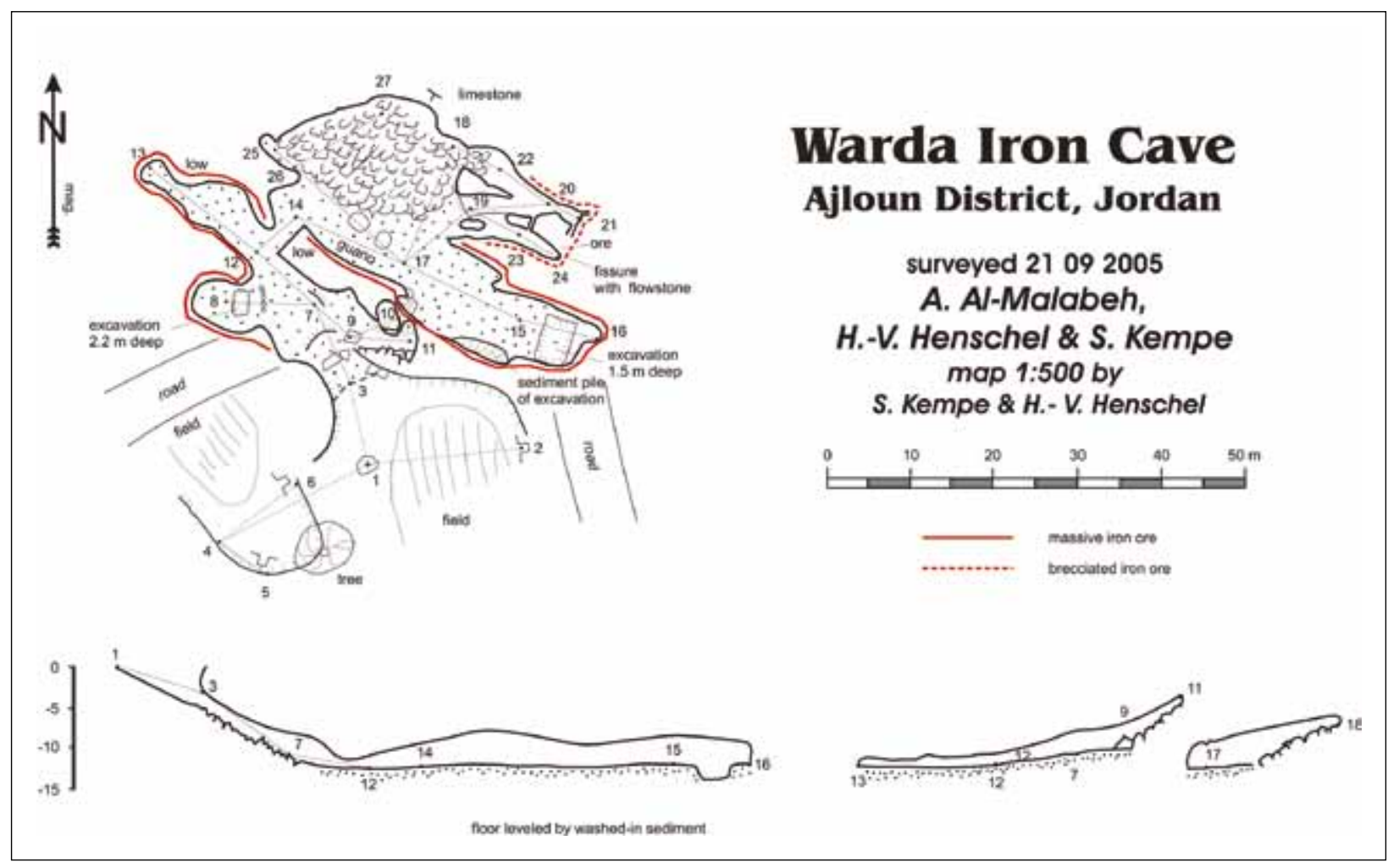

Fig. 3: Map and cross-sections of the historic Warda Iron Ore Mine/Ajloun District.

\section{WARDA IRON ORE DEPOSIT}

Besides the Warda Deposit, iron ores in Jordan occur in several other areas such as Amman (Abdoun), Jil'aad (30 $\mathrm{km} \mathrm{NW}$ of Amman) and Berain (10 km N of Amman). The extent of the mineralization is restricted in all areas and iron ores occur only in limited amounts.

The WID is situated east of the Dead Sea Transform Fault at $32^{\circ} 15^{\prime} 9^{\prime \prime} \mathrm{N}$ and $35^{\circ} 44^{\prime} 32^{\prime \prime} \mathrm{E}$ at an altitude of about $620 \mathrm{~m}$. The area was called locally Jabal Al-Aqra, i.e. "bald mountain" because of the former absence of the trees. Today the Ministry of Agriculture has reforested the area and it is now called Jabal Al-Akdar, i.e. "Green Mountain". The name Warda means "rose" in Arabic, due to the brilliant colors of the iron ore.

The first one to mention the occurrence of iron ore in Tell Qudeir (i.e., the former name of the WID) was Black in 1930. Boom \& Lahloub (1962, cited in Zitzmann 1976) studied the deposit in detail. The results of 15 boreholes indicate that the WID is $300 \mathrm{~m}$ long (striking SE-NW), $200 \mathrm{~m}$ wide and has a thickness that ranges between 0.8 and $9.8 \mathrm{~m} .205$ samples had an average of $47.5 \%$ Fe or $67.9 \% \mathrm{Fe}_{2} \mathrm{O}_{3}$. It was calculated that the deposit contains $265000 \mathrm{t}$ Fe. Intercalation with the surrounding limestone and floating limestone blocks in the ore were noticed as well as the absence of sulfides and the rarity of quartz and chalcedony. The iron minerals noticed were hematite and limonite, an identification probably based on macroscopy and not XRD. Boom \& Lahloub speculate that the deposit "was formed by hydrothermal, probably late-magmatic, epithermal metasomatism". Zagorac et al. (1968) conducted a geophysical survey of the WID using magnetic and geo-electrical methods and suggested a theoretical model for the spatial extension of the ore body. Bahsha (1968) excavated two tunnels and drilled 24 more boreholes and reported also that the thickness of the WID ranges from 0.8 to $10 \mathrm{~m}$. In 1985, Mikbel et al. (1985) mentioned the ore body but did not give any additional information. Batayneh (1987) carried out an additional magnetic survey and found that the WID has a thickness of up to $9.1 \mathrm{~m}$. Addalo \& Alhilali (1988) surveyed the soil above the WID and suggested a hydrothermal origin. Saffarini (1988) looked at the geochemical characteristics of carbonate-hosted Fe occurrences along the eastern Jordan Rift and studied (1989) the WID, finding between 22.1 to 59.03 wt\% Fe. Further- 


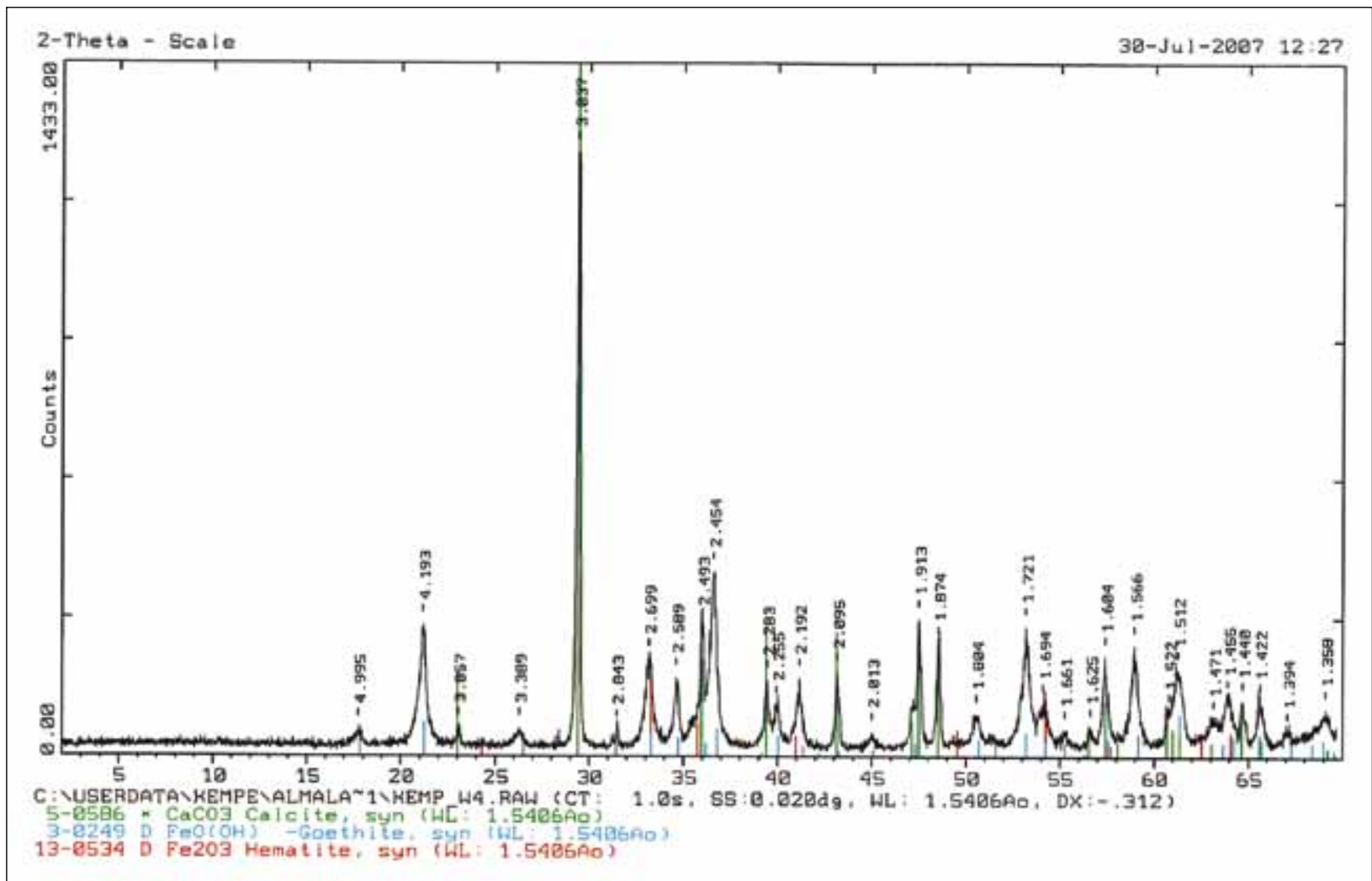

Fig. 4: X-ray diffraction 2 Theta plot of Sample W4 showing the main peaks of goethite (three principals d-values 4.193, 2.69, 2.452), calcite $(3.037,2.095,2.283)$, and hematite $(2.69,1.694,2.493)$.

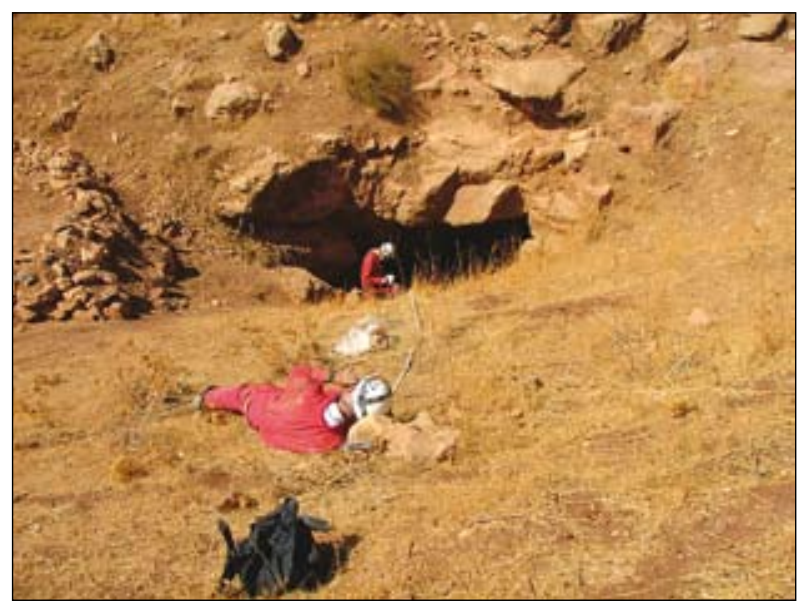

Fig. 5: Entrance of Ajloun iron ore mine. Survey work from st. 1 (foreground) to st. 3 (at entrance) in progress.

more, he also concluded that the ore is of hydrothermal origin. Finally, Saffarini \& Abu El-Haj (1997) carried out a geochemical soil survey for Fe at WID.

The pit mining exposed an ore body about $10 \mathrm{~m}$ thick (Fig. 2 a,b). It occurs as a band that is about $300 \mathrm{~m}$ long and $150 \mathrm{~m}$ wide striking NE-SW to NNE-SSW. The iron ores are oxidic, mostly of brown colors with yellow and black sections. The WID seems to be the only iron ore deposit in Jordan extensively mined historically and recently.

Even though the occurrence of the ore is limited, surface mining is still in progress. The ore is used in the cement industry for correction purposes and as construction material in the tile production. The most important period of mining was, however, the 11th century during the period of Salahuddin Al-Ayyubi (known also as Saladin), when one of his commanders, named Ezz Al-Deen Osma bin Mongeth, mined ores and used it in building Ajloun Castle, one of the most important fortifications against the crusaders. Mining was conducted in open pits and underground. A drill hole for blasting found in the mine suggests, that later (post 1700 or recent) investigations of the ore has also been conducted here.

\section{MINE AND CAVE}

The entrance to the Warda Iron Mine is situated below the road from Ajloun to the Jordan valley. A small agricultural field is nested in a sharp W-turn of the road. The field and a neighboring plot are partly surrounded by low cliffs that show several artificial openings (st. 2, 5 and 6). Only one of them, leading north underneath the road, 


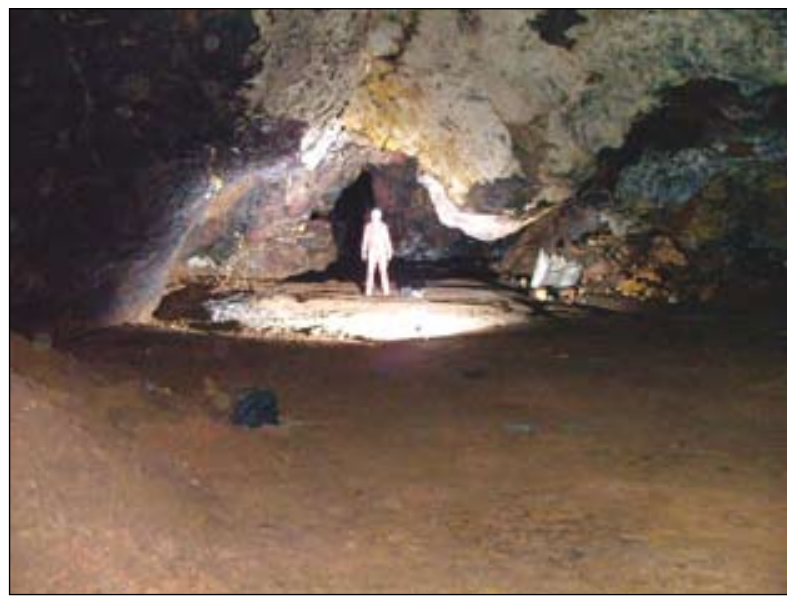

Fig. 6: View towards the NW in the inner hall. Note the flat floor covered with flashflood deposits. To the right a breakdown slope leads up to a limestone cupola. Note also the guano bags to the right.

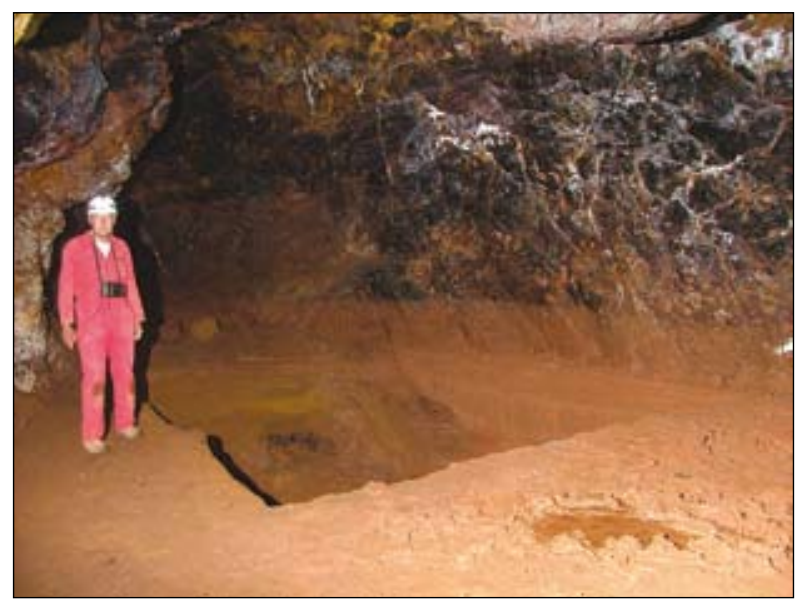

Fig. 7: View of the inner hall with the archeological pit towards st. 16. The passage is in massive oxidic iron ore and the floor has been leveled by flash flood deposits, ca. $1.5 \mathrm{~m}$ thick at the site of the pit. A high water mark is visible on the wall when the cave floods after heavy rainstorms.

gives access to an old mine (Fig. 5). The underground cavity consists of two larger, SE-NW striking, $40 \mathrm{~m}$-long rooms, connected by a low crawl (st. 13-14). The entrance room leads steeply down over blocks until the smooth floor of the mine is met, $12 \mathrm{~m}$ below st. 1 . This floor is the surface of consecutive flood deposits, washed into the mine during severe rains (Fig. 6). These reddish, silty sediments cover the original floor meter-deep, as can be seen in two archeological digs, one - in the entrance hall - being $2.2 \mathrm{~m}$ deep and the other - in the furthest corner of the second hall - being $1.5 \mathrm{~m}$ deep (Fig. 7). In the SE corner of the entrance hall, adjacent to breakdown blocks, jamming parts of the former, much larger entrance, two

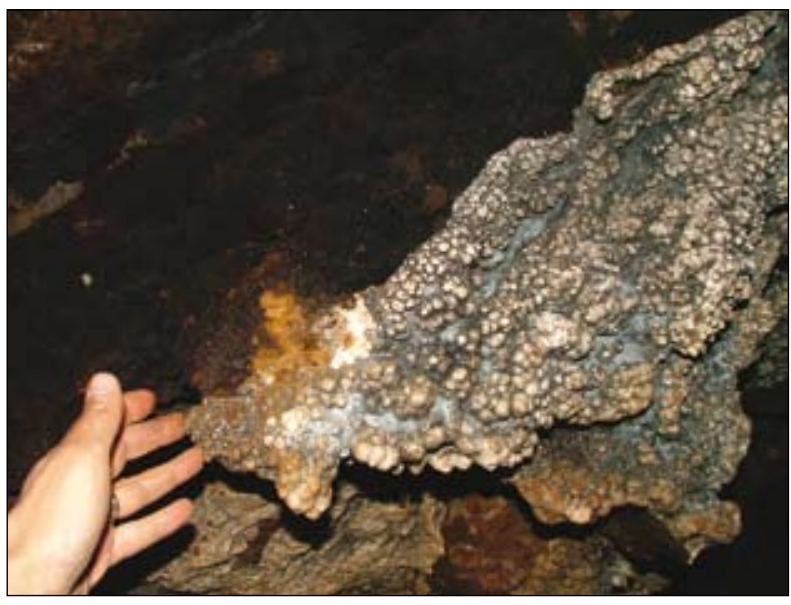

Fig. 8: Knobby wall speleothems indicate that part of the mine was an open natural cave.

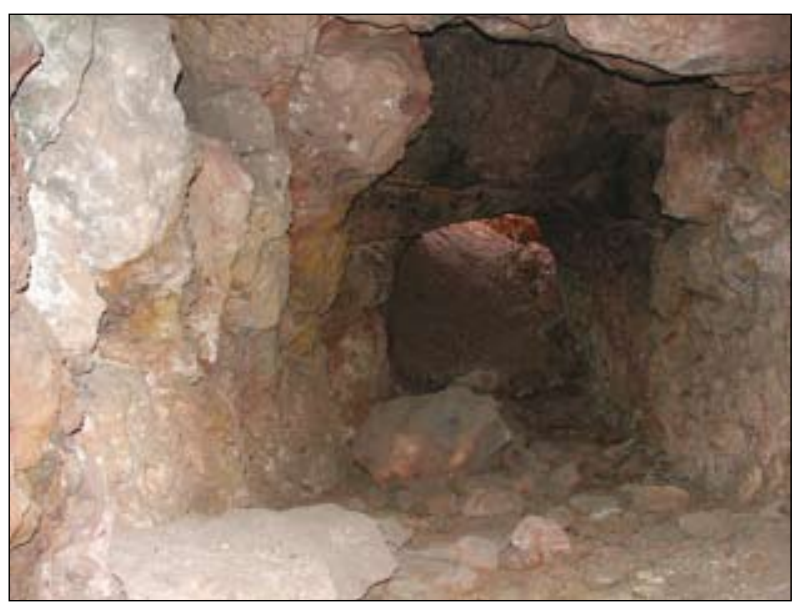

Fig. 9: Prospecting passage probably from the 1960's in the WID; view towards the entrance.

little mining chambers (st. 10 and 11) are found. Much of the lower part of the entrance camber (st. 12-13) is developed in the massive ore body. The far end (st. 15-16) of the second chamber is also dug out of the massive ore body while its northern parts are different. To the west, a large pile of breakdown blocks leads upwards, exposing SW - at ca. $40^{\circ}$ - dipping limestone strata in a large cupola. This part of the cavity does not look artificial it may though be a collapse of the mine roof into a once larger and deeper mining chamber. Here a sizable colony of bats lives. Bags show that the local inhabitants use the bat-guano as a resource of natural fertilizer (Fig. 6, to the right). In the SE corner, several passages are encountered that follow natural fissures through a brecciated ore body. These fissures are covered sparsely with wall speleothems (Fig. 8), showing that the miners found a certain amount of natural cavity when working the ore body. These fissures and their strike are most probably parallel to a fault, 
governing the valley in the cave area. We searched the mine rather thoroughly, but more passages may have existed originally now either buried under the invasive red dirt or by the breakdown pile.

The area of the surveyed cave is $980 \mathrm{~m}^{2}$ of which up to $640 \mathrm{~m}^{2}$ seem to be covered with flood sediments (entrance hall and southern section of inner hall). $230 \mathrm{~m}^{2}$ are occupied by the breakdown hall and the fissure-determined passages cover $100 \mathrm{~m}^{2}$. The flood debris may be $2 \mathrm{~m}$ thick on average (as indicated by the archeological digs) and the air space left may be $1 \mathrm{~m}$ (more in the center of the passages, much less towards the sides), thus the estimated volume of removed iron ore may be in the order of $640 \mathrm{~m}^{2} \mathrm{x}(2 \mathrm{~m}+1 \mathrm{~m})=920 \mathrm{~m}^{3}$. Adding some vol- ume from the fissure passages, all in all about $1000 \mathrm{~m}^{3}$ of ore has been mined, estimated conservatively. If we assume a $\mathrm{Fe}_{2} \mathrm{O}_{3}$ average of $50 \mathrm{wt} \%$, then goethite would have a weight percentage of $55.6 \%$ since we have to add one mol of water per mol of $\mathrm{Fe}_{2} \mathrm{O}_{3}$. The remaining $44.4 \%$ would be calcite. Thus one ton of ore would be $556.4 \mathrm{~kg}$ of goethite and $444 \mathrm{~kg}$ of calcite. Since the average density of goethite is $3.8 \mathrm{~g} / \mathrm{cm}^{3}$ and that of calcite $2.7 \mathrm{~g} / \mathrm{cm}^{3}$ one ton of ore would amount to $0.31 \mathrm{~m} 3$ and the total removed tonnage would be $1000 \mathrm{~m}^{3} / 0.31 \mathrm{t} / \mathrm{m}^{3}=3200 \mathrm{t}$ representing $1600 \mathrm{t} \mathrm{Fe}_{2} \mathrm{O}_{3}$ or about $1100 \mathrm{t}$ of elemental iron.

Nearby is a modern prospecting passage about $50 \mathrm{~m}$ long and $2 \times 2 \mathrm{~m}$ wide (Fig. 9), dug by the Natural Resource Authority (Bahsha 1968).

\section{ANALYTICAL METHODS AND TECHNIQUES}

\section{SURVEY}

On September $29^{\text {th }}, 2005$, we visited the only currently accessible historic iron mine at Warda and surveyed it because of its potential karstic setting and high geochemical and historic interest.

We used tape, laser distance meter (Hilti PD32), compass and inclinometer (both Silva Forest Master) in the survey (grade V survey accuracy according to British Cave Research Association), totaling 28 stations and $318 \mathrm{~m}$ of survey lines and numerous station-to-wall distance measurements. From the data a ground plan and cross-sections were constructed (Fig. 3). Representative rock samples were collected from different and typical outcrops of the WID within the mine for later X-ray diffraction (XRD; at Darmstadt), energy dispersive X-ray analysis (EDX, at Darmstadt) and X-ray fluorescence (XRF; at Erlangen) chemical analysis.

\section{XRD MINERAL IDENTIFICATION}

The samples ( $5 \mathrm{~g}$ each, finely ground in a rocker mill) were measured from $2^{\circ}$ to $70^{\circ} 2 \Theta$ with a step width of $0.02^{\circ} 2 \Theta$ and 2 seconds each step on a Philips PW 1830 diffractometer using $\mathrm{Cu} \mathrm{Ka}$ radiation and a graphite sin- gle crystal secondary monochromator. Based on the geological origin and on chemical composition, a high content of iron-rich mineral phases was expected. Although $\mathrm{Cu}$-radiation has not an ideal wavelength to detect ironrich minerals due to a high mass absorption coefficient and the production of secondary fluorescence radiation, the latter is removed by the secondary monochromator and iron-rich minerals can be easily detected if present in relatively high amounts (> $20 \% \mathrm{wt}$.). Mineral identification was performed using the Siemens Diffrac AT software (Version 2) based on the ICDD (2000) database.

\section{EDX CHEMICAL ANALYSIS}

EDX analysis was performed on the same samples that were analyzed by XRD. The finely ground samples were scanned at a magnification of 60 times at $25 \mathrm{KV}$ with a Fei-Quanta 200FEG and an EDX. The spectra accumulated over 30 seconds were recalculated for elemental composition by the ZAF method (Genesis Software by EDAX). The following elements were included in the calculations: C, O, Na, Mg, Al, Si, S, K, Ca, Fe (Table 2). No other element peaks occurred.

\section{RESULTS}

\section{XRD MINERAL IDENTIFICATION}

A total of five samples were investigated (Table 1). The following minerals were detected: Calcite, hematite and goethite. In Sample W1 a mineral is present that could not be clearly identified (d-values $=2.983,1.906,1.749)$. In review it was suggested that this mineral may be greigite $\left(\mathrm{Fe}^{2+} \mathrm{Fe}^{3+}\right) \mathrm{S}_{4}$. Its d-values (relative percentage intensities in brackets) are: 2.980 (100), 1.746 (77), 2.470 (55), 3.498 (32), 1.008 (31), 1.901 (29), 1.105 (16) (quoted from http:// rruff.geo.arizona.edu/doclib/hom/greigite.pdf). Thus the 
three reflexes of the unknown mineral are near to three of the greigite d-values (underlined). The remaining reflexes could be masked by those of the other iron minerals. In addition, sample $\mathrm{W} 1$ is the only one relatively rich in sulfur (Table 2). Since the $\mathrm{Fe} / \mathrm{S}$ ratio in greigite is 0.87 , a $\mathrm{S} w \mathrm{w} \%$ of 3.56 could bind about one eights of the present iron as greigite. Greigite should be magnetic, but a test with a very strong magnet did not indicate the presence of any magnetic particles. Fig. 4 gives the $2 \Theta$ plot of sample W4 as an example.

Table 1: XRD Results $(X X X=$ most prominent mineral; $X X=$ abundant $X=$ clearly detectable; ()$=$ possibly present). The second line is giving the color description of the ground sample according to Michel Farbenführer, 2000.

\begin{tabular}{|l|l|l|l|l|}
\hline Sample W1 & W2 & W3 & W4 & W5 \\
\hline $\begin{array}{l}\text { dark brown } \\
\text { orange }\end{array}$ & $\begin{array}{l}\text { dark orange } \\
\text { brown }\end{array}$ & blackish brown & blackish ochre & $\begin{array}{l}\text { blackish ochre } \\
\text { brown }\end{array}$ \\
\hline Calcite XXX & Calcite XXX & Hematite XXX & Goethite XXX & Goethite XXX \\
\hline Greigite?? XX & Goethite XX & Calcite XX & Calcite XX & Hematite XXX \\
\hline Hematite X & Hematite X & Goethite XX & Hematite X & Calcite X \\
\hline (Goethite) & & & & \\
\hline
\end{tabular}

thin speleothem calcite. Sample W4, from the pit again, is a highly fractured brown, calcite-sparitic ore with veins and crystals of a clear calcite. Finally, sample W5, from the cave, is similar to W3, i.e., a blackish, fine-grained and fractured ore of a high density, with fractures filled with reddish-brown (hematitic) fine-grained calcite.

\section{EDX CHEMICAL ANALYSIS}

EDX analysis was performed on the same samples that were analyzed by XRD. Samples were scanned at a magnification of 60 times at $25 \mathrm{KV}$ with a Fei-Quanta 200FEG and an EDX. The spectra accumulated over 30 seconds were recalculated for elemental composition by the ZAF method (Genesis Software by EDAX). The following elements were included in the calculations: $\mathrm{C}, \mathrm{O}, \mathrm{Na}, \mathrm{Mg}$, $\mathrm{Al}, \mathrm{Si}, \mathrm{S}, \mathrm{K}, \mathrm{Ca}, \mathrm{Fe}$ (Table 2). No other element peaks occurred.

Table 2: EDX analysis Samples W1 - W5.

\begin{tabular}{|l|r|r|r|r|r|r|r|r|r|r|}
\hline SampleNumber & \multicolumn{2}{|c|}{ W 1 } & \multicolumn{2}{|c|}{ W2 } & \multicolumn{2}{|c|}{ W3 } & \multicolumn{2}{|c|}{ W4 } & \multicolumn{2}{|c|}{ W5 } \\
\hline Element & $\mathbf{W t} \%$ & At \% & $\mathbf{W t} \%$ & At\% & $\mathbf{W t \%}$ & At\% & Wt\% & At\% & Wt\% & At\% \\
\hline C & 11.94 & 22.30 & 3.87 & 10.09 & 2.88 & 8.52 & 8.50 & 18.00 & 2.65 & 6.71 \\
\hline $\mathbf{O}$ & 34.32 & 48.11 & 22.57 & 44.12 & 16.78 & 37.27 & 32.91 & 52.29 & 27.33 & 51.99 \\
\hline Na & 0.64 & 0.62 & 0.37 & 0.50 & 0.00 & 0.00 & 0.56 & 0.62 & 0.43 & 0.57 \\
\hline Mg & 0.38 & 0.35 & 0.94 & 1.20 & 0.08 & 0.12 & 0.58 & 0.61 & 0.47 & 0.58 \\
\hline Al & 7.40 & 6.15 & 0.85 & 0.98 & 0.78 & 1.03 & 0.37 & 0.35 & 1.49 & 1.68 \\
\hline Si & 2.02 & 1.61 & 1.51 & 1.68 & 1.00 & 1.27 & 0.53 & 0.48 & 2.37 & 2.57 \\
\hline S & 3.56 & 2.49 & 0.21 & 0.21 & 0.27 & 0.30 & 0.24 & 0.19 & 0.24 & 0.23 \\
\hline K & 1.17 & 0.67 & 0.32 & 0.26 & 0.23 & 0.21 & 0.15 & 0.10 & 0.16 & 0.13 \\
\hline Ca & 13.96 & 7.81 & 9.57 & 7.46 & 6.71 & 5.94 & 10.02 & 6.36 & 0.91 & 0.69 \\
\hline Fe & 24.60 & 9.88 & 59.79 & 33.49 & 71.26 & 45.33 & 46.12 & 21.00 & 63.95 & 34.85 \\
\hline Total & 100.00 & 100.00 & 100.00 & 100.00 & 100.00 & 100.00 & 100.00 & 100.00 & 100.00 & 100.00 \\
\hline
\end{tabular}

Sample W1 was taken from the quarry above the cave, consisting mostly (in the un-ground state) of a reddish calcite, crisscrossed by brown-grey calcite veins, with hematitic crusts. Sample W2 is also from the quarry and is a dark brown, calcitic ore showing two generations of calcite veins. Sample W3 is from the ore body in the cave. It is a breccia of a blackish dark gray, fine-grained, noncalcitic ore of a high density, with calcitic brownish material filling the fractures and covered with cream-colored
The results match those of the $\mathrm{XRD}$ analysis. Fe is by weight the most important element ranging between 24.6 and $71.3 \%$ followed by Ca with 0.9 to $24.0 \%$. The oxygen concentration is not in proportion to its real content; for example in $\mathrm{W} 3$, if one takes the atom ratio of $\mathrm{Ca}$ (ca. 6 ) and subtracts $6 \times 3$ oxygen (because in $\mathrm{CaCO} 3$ we have three $\mathrm{O}$ for each $\mathrm{Ca}$ ) then only 19 atom\% of O remains. That is not enough to accommodate the 45 atom\% of $\mathrm{Fe}$ as either goethite or hematite. This mismatch is due 
to the fact that light elements ( $\mathrm{C}$ and $\mathrm{O}$ ) are generally not well represented in the EDX analysis.

Sample W1 has a high concentration of $\mathrm{Al}$ and S and a noticeable $\mathrm{K}$ peak is present. Thus one could also speculate that these elements may constitute the unidentified mineral found in the XRD spectrum. At first one thinks of potassium-alum $\left(\mathrm{KAl}\left(\mathrm{SO}_{4}\right)_{2} \times 12\left(\mathrm{H}_{2} \mathrm{O}\right)\right)$ or a mixture of it with Na-alum. However, neither the dvalues of the XRD agree with those of $\mathrm{K}$-alum (strongest d-values: 4.298 (1); 3.25(0.55); 4.053(0.45)) or Na-Alum (d-values: 4.314 (1); 2.962(0.35); 3.526 (0.14)), nor do the elemental ratios of $\mathrm{Al} / \mathrm{S}$ match (i.e. they should be 0.5 instead of ca. 2 as measured for W1). Thus greigite currently remains the best option.

\section{XRF CHEMICAL ANALYSIS}

Major (Table 3) and trace elements (Table 4) were determined for five more samples using the XRF at the Geological Institute, Erlangen University, Germany (Laboratory Prof. Dr. H.J. Tobschall). Sample IC 1 is from the flash flood sediment in the historic mine. Samples IC 2, 3 and 4 are samples of the ore body in the historic mine and sample IC5-calcite is a speleothem sample from the cave cut by the mine.

Table 3: Major elements (XRF) of the studied samples. $(R F=L a b$. No. Erlangen; $\mathrm{LOI}=$ Loss On Ignition; $\mathrm{Fe}_{2} \mathrm{O}_{3}{ }^{t}=$ total iron). Bold $=$ highest values; italics $=$ lowest values of ore samples (excluding IC5-calcite).

\begin{tabular}{|l|c|c|c|c|c|}
\hline Sample & $\begin{array}{c}\text { IC 1 } \\
\text { (sediment) } \\
\text { RF 9863 }\end{array}$ & $\begin{array}{c}\text { IC 2 } \\
\text { RF 9856 }\end{array}$ & $\begin{array}{c}\text { IC 3 } \\
\text { RF 9861 }\end{array}$ & $\begin{array}{c}\text { IC 4 } \\
\text { RF 9862 }\end{array}$ & $\begin{array}{c}\text { IC5-calcite } \\
\text { RF 9854 }\end{array}$ \\
\hline Oxide & $\%$ & $\%$ & $\%$ & $\%$ & $\%$ \\
\hline $\mathrm{SiO}_{2}$ & 6.4 & 0.1 & $\mathbf{1 2 . 0}$ & $<0.1$ & $<0.1$ \\
\hline $\mathrm{TiO}_{2}$ & 0.07 & 0.13 & $\mathbf{0 . 4 1}$ & 0.02 & $<0.01$ \\
\hline $\mathrm{Al}_{2} 03$ & $\mathbf{0 . 0 8}$ & 0.01 & 0.1 & 0.07 & 0.01 \\
\hline $\mathrm{Fe}_{2} \mathrm{O}_{3} \mathrm{t}$ & 36.77 & 62.29 & 27.31 & $\mathbf{7 3 . 7 6}$ & 0.07 \\
\hline $\mathrm{MnO}$ & $\mathbf{0 . 0 0 4}$ & 0.003 & 0.003 & $\mathbf{0 . 0 0 4}$ & 0.002 \\
\hline $\mathrm{Mg0}$ & 0.39 & 0.28 & $\mathbf{0 . 6 5}$ & 0.07 & 0.51 \\
\hline $\mathrm{Ca0}$ & 29.41 & 17.63 & $\mathbf{3 2 . 8 4}$ & 0.06 & 55.13 \\
\hline $\mathrm{Na}_{2} \mathrm{O}$ & $<0.01$ & $<0.01$ & $<0.01$ & $<0.01$ & $<0.01$ \\
\hline $\mathrm{K}_{2} \mathrm{O}$ & $<0.01$ & $\mathbf{0 . 0 1}$ & $<0.02$ & $<0.01$ & 0.01 \\
\hline $\mathrm{P}_{2} \mathrm{O}_{5}$ & 0.033 & 0.061 & 0.068 & $\mathbf{0 . 1 1 6}$ & 0.004 \\
\hline $\mathrm{SO}_{3}$ & $\mathbf{0 . 3 9}$ & 0.32 & 0.05 & 0.17 & $<0.01$ \\
\hline $\mathrm{Cl}$ & $\mathbf{0 . 0 8}$ & $\mathbf{0 . 0 8}$ & 0.07 & 0.06 & 0.09 \\
\hline $\mathrm{F}$ & 0.02 & 0.25 & $<0.01$ & $\mathbf{0 . 4 8}$ & $<0.01$ \\
\hline $\mathrm{LOI}$ & 27.5 & 15.22 & $\mathbf{2 7 . 8 9}$ & 10.34 & 43.78 \\
\hline $\mathrm{SUM}$ & 101.0 & 96.3 & 101.4 & 84.9 & 99.0 \\
\hline
\end{tabular}

Table 4: Trace element chemical analyses (XRF) of the studied samples. Bold = highest values; italics = lowest values of ore samples (excluding IC5-calcite).

\begin{tabular}{|l|c|c|c|c|c|}
\hline Sample & $\begin{array}{c}\text { IC 1 } \\
\text { (sediment) } \\
\text { RF 9863 }\end{array}$ & $\begin{array}{c}\text { IC 2 } \\
\text { RF 9856 }\end{array}$ & $\begin{array}{c}\text { IC 3 } \\
\text { RF 9861 }\end{array}$ & $\begin{array}{c}\text { IC 4 } \\
\text { RF 9862 }\end{array}$ & $\begin{array}{c}\text { IC5-calcite } \\
\text { RF 9854 }\end{array}$ \\
\hline $\begin{array}{l}\text { Trace } \\
\text { elements }\end{array}$ & ppm & ppm & ppm & ppm & ppm \\
\hline As & 11 & 14 & 4 & 168 & 3 \\
\hline $\mathrm{Ba}$ & 17 & 90 & 44 & 37 & 8 \\
\hline $\mathrm{Bi}$ & 3 & 5 & 4 & 6 & 2 \\
\hline $\mathrm{Ce}$ & 6 & 5 & 11 & $<1$ & 1 \\
\hline $\mathrm{Co}$ & 64 & 106 & 4 & 124 & 9 \\
\hline $\mathrm{Cr}$ & 5 & 16 & 21 & 5 & $<1$ \\
\hline $\mathrm{Cu}$ & $<1$ & $<1$ & 17 & $<1$ & $<1$ \\
\hline $\mathrm{Ga}$ & 2 & $<1$ & 5 & $<1$ & 2 \\
\hline $\mathrm{Hf}$ & 2 & 3 & 1 & 8 & $<1$ \\
\hline $\mathrm{La}$ & 8 & $<1$ & 20 & 13 & 3 \\
\hline $\mathrm{Mo}$ & $<1$ & $<1$ & $<1$ & 20 & 11 \\
\hline $\mathrm{Nb}$ & 2 & 2 & 5 & 2 & 1 \\
\hline $\mathrm{Ni}$ & $<1$ & $<1$ & $<1$ & $<1$ & $<1$ \\
\hline $\mathrm{Pb}$ & $<1$ & $<1$ & $<1$ & $<1$ & $<1$ \\
\hline $\mathrm{Rb}$ & 4 & 3 & $<1$ & 5 & $<1$ \\
\hline $\mathrm{Sr}$ & 32 & 38 & 53 & 5 & 43 \\
\hline $\mathrm{Ta}$ & $<1$ & 3 & $<1$ & 13 & $<1$ \\
\hline $\mathrm{Th}$ & 5 & 4 & 6 & 5 & 6 \\
\hline $\mathrm{U}$ & 5 & $<1$ & 3 & $<1$ & 5 \\
\hline $\mathrm{V}$ & 13 & 130 & 16 & 12 & $<1$ \\
\hline $\mathrm{W}$ & 69 & 109 & 32 & 248 & $<1$ \\
\hline & & & & & \\
\hline
\end{tabular}




\section{DISCUSSION OF RESULTS}

\section{THE ORE BODY}

In places, the WID shows a brecciated nature, possibly a consequence of the NNE-SSW striking faults in the area. Smaller fissures were filled with multi-generation calcite veins. Larger, open fractures were partly filled with speleothems. Large natural chambers may have existed within the ore body, as suggested by the irregular form of the mine and by the existence of a large breakdown cupola in limestone.

The best ore itself is a dark, blackish-grey, dense, fine-grained, calcite free and very iron-rich, almost pure goethite (samples W3, W5 and IC4). Less (or more??) altered parts of the ore body are more calcitic, brown and ochre in color. Hematite may be mixed into the goethite and occurs sometimes as reddish crusts. Samples W1 and W2 were collected from the quarry above the cave. The relatively high sulfur values together with the unclear XRD reflexes in sample W1 may hint at the presence of an iron sulfide, greigite. It is a low temperature mineral, even present in bacteria, and can form in sediments at low temperatures under reducing conditions (e.g., Roberts et al. 2006).

\section{a) Major elements}

\section{GEOCHEMISTRY}

The major element composition of the WDI (Table 3 ) shows that it is mainly characterized by high $\mathrm{Fe}_{2} \mathrm{O}_{3}$ concentrations, ranging from 27.3 to $73.8 \mathrm{wt} \%$ in the rock samples corresponding to the high Fe-concentrations found in the EDX-analysis (Table 2). The highest amount is found in sample IC4, representing the most characteristic and unaltered ore composition. Even the sediment sample still has 36.8 wt\% Fe. The Fe-concentration falls within the averages reported for WID by different authors (e.g., Saffarini 1988).

The $\mathrm{CaO}$ ranges from 0.06 to $32.84 \mathrm{wt} \%$ in the rock samples (with IC4 having the lowest value) and is 29.41 $\mathrm{wt} \%$ in the sediment. The speleothem sample expectedly has the highest $\mathrm{CaO}$ content, i.e., $55.1 \mathrm{wt} \%$.

The $\mathrm{SiO}_{2}$ content ranges from $<1$ to $12.0 \mathrm{wt} \%$ in the rock samples and reaches $6.4 \mathrm{wt} \%$ in the sediment. It is interesting to note, that we did not find any quartz in the XRD samples so that the $\mathrm{SiO}_{2}$ most probably is in the form of amorphous chert.

The $\mathrm{TiO}_{2}$ ranges from 0.02 to $0.41 \mathrm{wt} \%$ in the rocks sample and reaches an intermediate concentration in the sediment, i.e. $0.07 \mathrm{wt} \% . \mathrm{MnO}, \mathrm{Al}_{2} \mathrm{O}_{3}$ and $\mathrm{P}_{2} \mathrm{O}_{5}$ are all low in concentrations ranging from 0.003 to $0.0004,0.01$ to 0.1 , and 0.06 to $0.116 \mathrm{wt} \%$, respectively. Similarly are $\mathrm{Na}_{2} \mathrm{O}$ and $\mathrm{K}_{2} \mathrm{O}$ are very low, i.e., below $<1 \mathrm{wt} \%$.

Sample IC4 certainly is the most original ore sample. It contains the highest $\mathrm{Fe}, \mathrm{P}$ and $\mathrm{F}$ and the lowest $\mathrm{Si}, \mathrm{Ti}$,
$\mathrm{Mg}$ and $\mathrm{Ca}$ concentrations of the ore samples. Even when considering that the added total amounts to only $84.9 \%$ and recalculating the concentrations to $100 \%$ sum, this statement would hold. If the LOI is entirely water (which is a permissible assumption since the $\mathrm{Ca}$ and $\mathrm{Mg}$ concentrations and therefore the $\mathrm{CO}_{2}$ concentrations are so low) then all of Fe can be present in the form of goethite: $18(73.76 / 159.68)=8.3 \% \mathrm{H}_{2} \mathrm{O}$ compared to $10.34 \mathrm{wt} \%$ $\mathrm{H}_{2} \mathrm{O}$ present. Thus the original ore seems to have been deposited as goethite. Since $2 \%$ more LOI is present than necessary for the goethite, is must be assumed that a noticeable fraction of the ore contains more water, i.e., that it is limonitic and therefore not XRD detectable. Later dissolution of the ore has enriched it with $\mathrm{Ti}$, removed $\mathrm{P}$ and $\mathrm{F}$ and diluted it with $\mathrm{Ca}$ and $\mathrm{Mg}$ carbonates. The overall low $\mathrm{Mn}$ values are also remarkable for an iron ore. The very low $\mathrm{P}_{2} \mathrm{O}_{5}$ concentration suggests that the goethite is a high-grade iron ore, easily processed to make very good and non-brittle steel.

\section{b) Trace elements}

Also the concentrations of the trace elements (Table 4) show distinctive variations. Almost all of the elements vary by more than an order of magnitude in concentration between samples, with the exception of Th and $\mathrm{Y}$.

Many of the more common heavy metals show overall low concentrations specifically $\mathrm{Cu}, \mathrm{Ni}$ and $\mathrm{Pb}$. The $\mathrm{Zn}$ content is also relatively low, ranging from $<1$ up to $33 \mathrm{ppm}$ in the rocks and about $2 \mathrm{ppm}$ in the sediments. This value is lower than the average value of 124 ppm reported for the WID by Saffarini (1988). Sr-values are rather low, considering that the deposit is situated in a marine limestone.

Other, less common elements such as As, Co, V and $\mathrm{W}$ show overall much higher concentrations. In fact $\mathrm{W}$ has the highest concentration of all trace metals in sample IC4.

Goethite sample IC4 and speleothem sample IC5calcite seem to be sort of end-members with the other two rocks and the sediment sample mostly showing intermediate values. In IC4 As, Co, Hf, Mo, Rb, Ta, W and $\mathrm{Zn}$ show highest and $\mathrm{Ce}, \mathrm{Sr}, \mathrm{V}$ and $\mathrm{Zr}$ lowest values of the batch, while in the calcite all values are very low with the exception of Mo, Sr, and U, elements that can accommodate relatively well in the calcite lattice. The soil sample IC1 ranges for almost all of the elements between IC4 and IC5-Calcite with the exception of Ce, Mo, $\mathrm{Zn}$ and $\mathrm{Zr}$. The ore samples IC2 is special in its relatively high, $\mathrm{Co}, \mathrm{Cr}, \mathrm{Sr}$ and $\mathrm{W}$ and has the highest $\mathrm{Ba}$ and $\mathrm{V}$ concentrations and the sample IC3 is highest in $\mathrm{Ce}, \mathrm{Cr}, \mathrm{Cu}, \mathrm{Ga}$; $\mathrm{La}, \mathrm{Nb}, \mathrm{Sr}$ and $\mathrm{Zr}$ and lowest in $\mathrm{As}, \mathrm{Co}, \mathrm{Rb}$ and $\mathrm{W}$. 


\section{CONCLUSIONS}

Even though the ore body appears to be striking parallel to the local fault, the ore body seams to be stratiform. This is indicated by the older prospecting results, the lens-shape of the ore body in the pit mine and by the fact that the historic mine shows a horizontal development. Also, the local NNW-SSE striking fault most likely caused the brecciation of the ore body, i.e., we must conclude that the genesis of the goethitic ore body predates the faulting.

The presence of a significant amount of hematite in the ore body can be interpreted to be a secondary alteration, caused either by cool, very dense solutions at low temperatures or by temperatures above $140^{\circ} \mathrm{C}$ (or $220^{\circ} \mathrm{C}$ using different thermodynamic constants) when goethite in the presence of water can be dehydrated (Bischof 1969). Such a temperature could have been reached either during the faulting process or during burial of the deposit prior to its uplift. The possible presence of greigite in a section of the ore body that has higher sulfur content could hint at slightly reducing conditions during the formation of the central part of the deposit (exposed in the quarry above the mine). It also is a lowtemperature mineral.

Many models can be discussed regarding the potential genesis of the WID, among them: 1) syn-sedimentary deposition, 2) hydrothermal marine, 3) metasomatic, 4) weathering of a basaltic precursor or 5) speleogene (phreatic-hypogene).

Model 1 can be excluded, because of the texture of the ores and fact that the goethite is very pure. Model 2 can be excluded because of the low Sr values in our samples. Extensive analytical data exist for the hot brine goethitic sediments in the Red Sea brine basins (Hendricks et al. 1969). All of the samples measured have a much higher Sr content (as is typical for marine deposits) much higher Mn and much lower W concentrations. Model 3 most probably can also be excluded since high-temperature metasomatic deposits have a different paragenesis, including originally deposited siderite, veins of quartz, barite and co-precipitated heavy metal sulfides, all of them missing in the WID. An example of a metasomatic iron ore, its mineralogy, caves and mine systems has been investigated by one of us (SK) in the Iberg (Harz, Germany). There caves formed post-depositional by the hypogene in-situ liberation of $\mathrm{CO}_{2}$ due to the oxidation of the metasomatic siderite $\left(\mathrm{FeCO}_{3}\right)$ (e.g., Kempe 1998). Based on that experience a metasomatic genesis appears to be highly unlikely for the WID. The weathering of basalts (Model 4), a process that can also lead to pure iron oxides (i.e., Al-Malabeh \& Kempe 2005) is also not very likely; first of all, no basalt is known from the vicinity and second, remnant textures should be noticeable and third the albitization of the plagioclases during weathering should have left a noticeable Na-content.

Thus the last, the speleogene model remains to be explored. In speleology it is now an accepted fact (for an overview see Klimchouk 2007 and review by Kempe 2007) that many limestone caves, and among them some of the largest known, have been formed by ascending waters below the water table (i.e., deep-phreatic) by slow gravity-driven convection. In order to generate in-situ dissolutional capacity for these very large cavities, the bacterially mediated reaction, between an anaerobic, ascending phase and an aerobic descending phase at low temperatures is assumed. The reaction between both can then generate protons that serve to dissolve the limestone around the ascending plume of water. Water loaded with $\mathrm{H}_{2} \mathrm{~S}$ or $\mathrm{CH}_{4}$ would not be aggressive, but if oxidized, the resulting acids $\left(\mathrm{H}_{2} \mathrm{SO}_{3}\right.$ and $\left.\mathrm{H}_{2} \mathrm{CO}_{3}\right)$ would provide dissolutional capacity. In case of Carlsbad Cavern internal gypsum deposits show that the ascending gas was mostly $\mathrm{H}_{2} \mathrm{~S}$. If the gas is $\mathrm{CH} 4$, its oxidation and the consecutive dissolution do not leave any traces, possibly with one exception: Goethite. Under anaerobic conditions, when sulfide is missing, iron could be mobilized as $\mathrm{Fe}^{2+}$. If such a solution would be mixed with sinking $\mathrm{O}_{2}$-containing water, the $\mathrm{CH}_{4}$ would be oxidized bacterially; $\mathrm{CO}_{2}$ would be produced to dissolve the limestone and at the same time goethite would be precipitated. Thus it is conceivable, that under such conditions, small-scale goethitic ore bodies could be formed speleogeneticly. Similarly, $\mathrm{W}^{4+} \mathrm{O}_{2}$ (solubility $10 \mathrm{mg} / \mathrm{l}$ not depending on $\mathrm{pH}$ if $<10$ ) is more soluble than $\mathrm{W}^{6+} \mathrm{O}_{3}(0.1-2 \mathrm{mg} / \mathrm{l}$ depending on increasing pH) (Dermatas et al. 2004), thus being co-precipitated with Fe upon oxidation and explaining the high tungsten concentration in sample IC4.

To our knowledge there are several examples of goethite deposits in hypogene caves. None of them are well published. The most impressive one is the goethite deposit in the gigantic cave found near Wülfrath/ North Rhine-Westfalia/Germany. A quarry (Rohdenhaus-Süd) in Devonian massive limestone uncovered an enormous, at least $700 \mathrm{~m}$ long, $200 \mathrm{~m}$ wide and $20 \mathrm{~m}$ high cavity filled completely with quartz sand that contained lower Cretaceous plant remains (Drozdzewski et al. 1998). In the centre, a $10 \mathrm{~m}$ thick limonitic ore deposit at least $50 \mathrm{~m}$ wide was discovered, filling the space above the sedimentary deposits. This ore body possibly marks the site of the ascending waters, comparable to the deep sea chimneys of black smokers. This cave is one of the largest natural cavities yet discovered and clearly of hypogene origin, created by some sort of in-situ acid generating 
reaction. The iron ore has not yet been investigated in detail.

In a more recent cave, the Bismarck Cavern, Frankonia/Germany, we also observed stalactitic or chimney-like goethite deposits at the floor. This cave is also of hypogene origin and the goethite may be the only clues as to its real formation mechanism.

Therefore, it is conceivable that the WID formed in a similar way. This speleogene lagerstaetten-model, admittedly quite hypothetical, would account for the stratiform character of the deposit, for its situation within a marine limestone sequence, for its missing marine trace metal imprint in the ore and for the missing high temperature signature of the mineral paragenesis. The model would also account for the observed limestone blocks floating in the ore; they could be interpreted as roof collapse of the original cave. When looking at the geological development of the area and assuming the speleogene model to be correct, then the deposit could have formed at the end of the marine sedimentation in the area, when plate stress began to open up fractures into the basement. From there, methane (and $\mathrm{Fe}^{2+}$ ) rich solutions could have ascended high into the limestone series. Where they met sinking, oxygen-rich surface waters, bacterial oxidation and the resulting $\mathrm{H}_{2} \mathrm{CO}_{3}$ would have provided for the formation of a large cave. At the same time the ferrous iron would be oxidized and precipitated as water-rich goethitic limonite in the growing cave. As pressure and temperature increased, the bacterial reaction ceased and some of the goethite was dehydrated to hematite. Further increase of the N-S pressure on the plate led to a brecciation of the ore body and to the formation of calcite veins. Once lifted to altitudes of several $100 \mathrm{~m}$ a.s.l., water, circulating through the breccia, could form small cavities and speleothems could start to grow.

This model, developed according to the present state of knowledge could serve as a starting point to investigate similar deposits and the Warda Iron Deposit could serve as a locus typicus for a new type of iron ore deposits not well studied yet.

In a sense, the finding of Al-Daher Cave as described in the introduction and its hypogene nature, illustrates that effective speleogene systems involving ascending water plumes have existed in Jordan in the past. They therefore may have played a much more important role than hitherto acknowledged.

\section{ACKNOWLEDGEMENTS}

The authors would like to thank the Hashemite University for providing a pickup as well as Mr. Osma Al-Turk for his long hours of driving during the field work and T. Dirsch (Darmstadt) for his help with the EDX-analy- sis. The authors are also grateful for the reviews by Nadja Zupan Hajna and Andrej Kranjc that helped improving the paper.

\section{REFERENCES}

Addalo, A. \& Alhilali, E., 1988: The geochemical study of iron occurrences in the Warda area. - Unpublished report, NRA, Jordan.

Al-Malabeh, A., 1994: Geochemistry of two volcanic cones from the intra-continental plateau basalt of Harra El-Jabban, NE-Jordan. - Geochemical Journal, 28, 517-540.

Al-Malabeh, A. \& Kempe, S., 2005: Origin of iron ore nuggets ("Bohnerze") through weathering of basalt as documented by pebbles from the Herbstlabyrinth, Breitscheid-Germany. - Acta Carsologica, 34(2), 459-470.

Al-Malabeh, A. Al-Fugha, H., \& El-Hasan, T., 2004: Petrology and geochemistry of Late Precambrian magmatic rocks from southern Jordan. - N. Jb. Palaent. Abh., 233 (3), 333-350.
Al-Malabeh, A., Kempe, S., Frehat, M. \& Henschel, H.V., 2007: Geo-conservation of the newly discovered Kufranja Cave, N-Jordan, a potential natural heritage site. - Abstracts Vol. Sixth International Symposium on Eastern Mediterranean Geology, Amman April 2-5, 2007, 174.

Bahsha, S., 1968: Stratigraphy, occurrence, origin and prospecting at Warda/south Ajloun District. - Unpublished report. Nat. Res. Authority, Amman.

Barazangi, M., 1983: A summary of the seismotectonics of the Arab region. - In: Cidlinsky, K., \& Rouhban, B., (eds.), "Assessment and Mitigation of Earthquake Risk in the Arab Region", Paris, France, UNESCO, 43-58.

Batayneh, A., 1987: Geophysical studies of iron occurrences in northern Jordan. - Unpublished MSc. thesis, University of Jordan, $150 \mathrm{pp}$. 
Bender, F., 1974: Geology of Jordan. - Bornträger, Berlin, Stuttgart, $196 \mathrm{pp}$.

Bischoff, J.L., 1969: Goethite-hematite stability relations with relevance to sea water and the Red Sea system. - In: Degens, E.T., \& Ross, D.A. (eds.), "Hot Brines and Recent Heavy Metal Deposits in the Red Sea, A Geochemical and Geophysical Account", Springer Verlag, New York, 402-406.

Boom, G. van den, \& Lahloub, G., 1962: The iron-ore deposits of Warda in southern Ajloun-District. - Unpulished report s. Zitzmann, 1976.

Dermatas, D., Braida, W., Christodoulatos, C., Strigul, N., Panikov, N., Los, M., \& Larson, S., 2004: Solubility, sorption, and soil respiration effects of tungsten and tungsten alloys. - Environmental Forensics, 5(1), 5-13.

Drozdzewski, G., Hartkopf-Fröder, C., Lange, F.-G., Oestreicher, B., Ribbert, K.-H., Voigt, S. \& Vrede, V., 1998: Vorläufige Mitteilung über unterkretazischen Tiefenkarst im Wülfrather Massenkalk (Rheinisches Schiefergebirge). - Mitt. Verb. dt. Höhlen- u. Karstforscher, 44(2), 53-66.

Emiliani, C., 1992:. Planet Earth. - Cambridge Univ. Press, New York, 719 pp.

Freund, R., Zak, I., \& Garfunkel, Z., 1968: Age and rate of the sinistral movement along the Dead Sea Rift. - Nature, 220, 253-254.

Freund, R., Garfunkel, Z., Zak, I., Goldberg, M., Weissbrod, T., \& Derin, B., 1970: The shear along the Dead Sea Rift. - Philos. Trans. R. Soc. London, A267, 107-130.

Garfunkel, Z., 1981: Internal structure of the Dead Sea leaky transform (rift) in relation to plate kinematics. - Tectonophysics, $80,81-108$.

Girdler, R.W., 1990: The Dead Sea transform fault system. - Tectonophysics, 180, 1-13.

Hendricks, R.L., Reisbick, F.B., Mahaffy, E.J., Roberts, D.B., \& Peterson, M.N.A., 1969: Chemical composition of sediments and interstitial brines from the Atlantis II, Discovery and Chain Deeps. - In: Degens, E.T., \& Ross, D.A. (eds.), "Hot Brines and Recent Heavy Metal Deposits in the Red Sea, A Geochemical and Geophysical Account”, Springer Verlag, New York, 407-440.

Kazmin, V.G., 2002: The late Paleozoic to Cainozoic intraplate deformation in North Arabia: a response to plate boundary-forces. - European Geosciences Union (EGU) Stephan Mueller Spec. Publ. Ser., 2, $123-138$.

Kempe, S., 1998: Siderite weathering, a rare source of $\mathrm{CO}$ for cave genesis: The Eisensteinstollen System and adjacent caves in the Iberg, Harz Mountains, Germany. - Proc. 1998 Nat. Speleol. Soc. Conv. Sewanee, TN, 3.-7.8.1998, 78.
Kempe, S., 2007: Das neue Buch von Alexander Klimchouk zur hypogenen Speläogenese. - Mitt. Verb. dt. Höhlen- u. Karstforscher, 53(3), 90-93.

Kempe, S., Al-Malabeh, A., Al-Shreideh, A., \& Henschel, H.-V., 2006: Al-Daher Cave (Bergish), Jordan, the first extensive Jordanian limestone cave: A convective Carlsbad-type cave? - J. Cave and Karst Studies, 68 (3), 107-114.

Kempe, S., Al-Malabeh, A., Frehat, M., \& Henschel, H.-V., 2008: State of lava cave research in Jordan. - Proc. 12 ${ }^{\text {th }}$ Intern. Symp. on Vulcanospeleology, Tepotzlán, Mexico, 2-7 July, 2006, Assoc. for Mexican Cave Studies, Bull. 19 and Socieded Mexicana de Exploraciones Subterráneas Bol. 7, 209-218.

Klimchouk, A., 2007: Hypogene Speleogenesis: Hydrogeological and Morphogenetic Perspective. - National Cave and Karst Research Institute, Special Paper 1, 106 pp.

Mikbel, S., Saffarini, G. \& El-Isa, Z., 1985: New iron occurrence west of Amman, Jordan. - Dirasat, 12, 112-124.

Picard, L., 1970: On Afro-Arabian graben tectonics. Geol. Rdsch., 59, 337-382.

Pohl, W.L., 2005: Mineralische und Energie-Rohstoffe. E. Schweizerbart'sche Verlagsbuchhandlung, Stuttgart, $527 \mathrm{pp}$.

Quennell, A.M., 1958: The structural and geomorphic evolution of the Dead Sea Rift. - Quarterly J. Geol. Soc. London, 114, 1-24.

Roberts, A.P., Rowan, C.J., Horng, C.S., \& Florindo, F., 2006: Why every paleomagnetist should care about greigite. - Geophys. Res. Abstr., 8, 09122.

Saffarini, G., 1988: Ferride elements abundance in the carbonate-hosted iron occurrences of Jordan. - Dirasat (Science), 15(9), 190-202.

Saffarini, G., 1989: Geochemical characterization of a carbonate-hosted hydrothermal iron ore: The Warda iron deposit/Ajloun, Jordan. - Dirasat (Science), 16(8), 46-63.

Saffarini, G., \& Abu El-Haj, M., 1997: A geochemical soil survey for Fe at Warda iron occurrence, north Jordan. - Abhath Al-Yarmouk, 6(2), 153-157.

Zagorac, Z., Karmoul, A. \& El-Kaysi, K., 1968: Warda (Ajlun) iron ore deposit, geophysical investigations. - Unpubl. Report, NRA, Amman, Jordan, 30 pp.

Zitzmann, A., 1976: The iron ores in Jordan. - In: Zitzmann, A. (ed.) "Iron Ore Deposits of Europe and Adjacent Areas, Vol. 1”, Bundesanst. f. Geowiss. u. Rohstoffe, Hannover, p. 219. 
